\title{
Laporan Kasus: Tatalaksana Hematoma Akibat Trauma
}

\author{
(Case Report: Management of Traumatic Hematoma)
}

Fanni Kusuma Djati ${ }^{1}$, Chrystina Kusuma Dewi ${ }^{*}$

${ }^{1}$ Bagian IImu Penyakit Mulut, Jurusan Kedokteran Gigi, Fakultas Kedokteran UNSOED

2 Program Pendidikan Profesi, Jurusan Kedokteran Gigi, Fakultas Kedokteran UNSOED

\begin{abstract}
Abstrak
Hematoma merupakan kumpulan ekstravasasi darah yang besar akibat adanya trauma sehingga menimbulkan massa yang teraba. Penyebab hematoma biasanya karena trauma atau akibat adanya gangguan perdarahan pada sistemik. Diagnosis banding lesi ini berupa ekimosis dan hemangioma. Perlu dilakukan pemeriksaan dan anamnesa yang kuat untuk menentukan diagnosisnya. Hematoma biasanya tidak memerlukan perawatan karena self limiting. Seorang wanita usia 19 tahun datang untuk kontrol setelah 1 minggu dilakukan pembersihkan karang gigi/ scaling. Terdapat pembengkakan yang tidak disadari pasien berada di bawah lidah berwarna merah gelap dengan ukuran $\pm 2 \mathrm{~mm}$. Pasien tidak ada riwayat penyakit sistemik. OHIS baik dan pemeriksaan obyektif lainnya dalam batas normal. Terapi yang diberikan berupa edukasi kesehatan gigi dan evaluasi lesi selama \pm 1 minggu. Hematoma umumnya disebabkan oleh trauma sehingga terjadi ekstravasasi darah ke jaringa yang mempengaruhi pembuluh darah yang mendasarinya. Hematoma dapat menghilang secara spontan sehingga tidak perlu dilakukan perawatan.
\end{abstract}

Kata kunci : hematoma, rongga mulut, trauma

\begin{abstract}
Hematoma is a large collection of extravasation of blood due to trauma, causing a palpable mass. The cause of hematoma is usually due to trauma or due to a systemic bleeding disorder. The differential diagnosis of this lesion is ecchymosis and hemangioma. A strong examination and history are needed to determine the diagnosis. Hematomas usually do not require treatment because of self-limiting. A 19-year-old woman came for control after 1 week of cleaning tartar/scaling. There was a swelling that the patient does not realize is under the dark red tongue with a size of $\pm 2 \mathrm{~mm}$. The patient had no history of systemic disease. OHI-S is good and other objective examinations are within normal limits. Therapy was given in the form of dental health education and evaluation of lesions for \pm 1 week. Hematomas were generally caused by trauma resulting in extravasation of blood to the tissues that affect the underlying blood vessels. Hematoma could disappear spontaneously so there is no need for treatment.
\end{abstract}

Keywords: hematoma, oral cavity, trauma

Korespondensi (Correspondance) : Chrystina Kusuma Dewi, Fakultas Kedokteran, UNSOED, Purwokerto, Indonesia, email : chrystinakd@gmail.com.

Hematoma merupakan kumpulan ekstravasasi darah yang besar akibat adanya trauma sehingga menimbulkan massa yang dapat teraba. Hematoma adalah salah satu bentuk purpura, yaitu pewarnaan yang berbatas jelas yang ditimbulkan oleh perdarahan di bawah permukaan kulit.' Perkiraan tingkat perdarahan tahunan yaitu $0,6 \%$ perdarahan fatal, $3 \%$ perdarahan besar, dan $9,6 \%$ perdarahan ringan. ${ }^{2}$ Lesi akibat perdarahan ini tidak ditularkan dan tidak ditransmisikan kepada individu lainnya, serta tidak berpengaruh terhadap usia dan gender. ${ }^{1,3}$

Penyebab hematoma biasanya karena trauma, baik itu trauma yang tidak disengaja atau trauma iatrogenik. Trauma dapat berasal dari tergigitnya mukosa, trauma iatrogenik berupa penggunaan high speed suction tips, anestesi lokal maupun trauma pascaoperasi. ${ }^{3}$ Pada beberapa pasien, dapat muncul tipe hematoma yang umumnya disebut liver dot pasca ekstraksi gigi atau prosedur bedah oral lainnya. Hematoma jenis ini merupakan tampakan lesi benwarna merah gelap seperti gumpalan hemoglobin dan disebabkan oleh perdarahan vena yang mengalir dengan lambat. Pada kasus lainnya, hematoma dapat menyebabkan obstruksi saluran nafas karena pembentukan hematoma yang luas pada dasar mulut sebagai komplikasi dari prosedur bedah. Perlu diperhatikan ketika melakukan prosedur implan, ekstraksi gigi, torektomi, atau osteotomi pada mandibular untuk menghindari cedera pada cabang arteri fasial atau sublingual. Selain itu, hematoma juga dapat disebabkan oleh adanya gangguan platelet atau proses pembekuan darah (hemophilia, von Willebrand disease), trombositopenia (kemoterapi, leukemia, idiopathic thrombocytopenic purpura /ITP), gangguan pada pembuluh darah jaringan ikat yang rapuh (scurvy, senile purpura). ${ }^{4}$

Secara klinis, hematoma terlihat berupa massa eritema berwarna coklat hingga merah tua atau ungu. Ukuran dari lesi ini bervariasi dari kecil hingga besar tergantung dari luasnya trauma.3.4 Jaringan yang mengalami hematoma tidak memucat apabila ditekan. Hal ini dikarenakan lesi ini berupa ekstravasasi darah dimana hasil dari tes diaskopi negatif. Umumnya hematoma dapat ditemukan pada daerah yang mudah 
terkena trauma seperti mukosa bukal, lidah, dan mukosa labial.1.4 Beberapa literatur menyebutkan bahwa lesi ini tidak menular dan tidak bertransmisi ke individu lainnya. Lesi ini dapat terjadi di semua umur baik wanita maupun pria. ${ }^{5}$

Lesi ini tidak memerlukan perawatan jika lesi berukuran kecil karena lesi ini akan menghilang secara spontan, namun pasien tetap perlu diedukasi terkait keberadaan lesi ini. Lesi yang ukurannya lebih besar biasanya akan menekan daerah dimana lesi tersebut ada, sehingga dapat diberikan es sesaat setelah trauma. ${ }^{3,5}$

\section{LAPORAN KASUS}

Seorang wanita usia 19 tahun datang ke klinik Integrasi A RSGMP Unsoed Purwokerto untuk kontrol setelah 1 minggu dilakukan pembersihkan karang gigi/ scaling. Berdasarkan pemeriksaan umum, keadaaan umum compos mentis (baik), berat badan 75 $\mathrm{kg}$, tinggi badan $165 \mathrm{~cm}$, tekanan darah 120/80 $\mathrm{mmHg}$, nadi $83 \mathrm{x} /$ menit, pernafasan 15 $\mathrm{x} /$ menit, suhu afebris.

Pada pemeriksaan intraoral, pembengkakan dan perdarahan pada papilla interdental hingga gingiva marginalis sudah berkurang, bahkan sudah tidak ada perdarahan spontan. Tidak ada dehisensi dan fenestrasi pada seluruh regio. Pada gingiva terdapat stipling, resesi gingiva pada gigi 31 berkurang menjadi $2 \mathrm{~mm}$ dari $4 \mathrm{~mm}$. OHIS 0,667 (baik), pasien tidak ada keluhan, namun terdapat lesi intraoral yang tidak disadari pasien. Lesi tersebut berupa pembengkakan di bawah lidah benwarna merah gelap dengan ukuran $\pm 2 \mathrm{~mm}$. Awalnya daerah ujung lidah tersebut tidak sengaja tergigit sekitar \pm 5 hari lalu. Saat tergigit timbul rasa sakit dan benjolan, namun rasa nyeri semakin hilang. Pasien memiliki riwayat sesak nafas, tetapi sudah lama tidak kambuh. Pasien dan keluarganya tidak memiliki riwayat sistemik lainnya. Pasien sudah pernah melakukan perawatan dental berupa pembersihan karang gigi/ scaling. Pasien adalah seorang mahasiswi. Pemeriksaan ekstra oral menunjukkan wajah simetris, warna sekitar sawo matang, mata normal, tidak terdapat pembengkakan, mata sejajar, warna sekitar mata normal, warna sklera ikterik, warna kelopak mata bagian dalam merah muda, tidak terdapat pembengkakan pada leher, tangan dan jari normal, tidak terdapat pembengkakan limfonodi, dan tidak terdapat gangguan TMJ.

Pada pemeriksaan intraoral terlihat adanya lesi berupa massa, berukuran $\pm 2 \mathrm{~mm}$, tunggal, berwarna merah gelap, konsistensi kenyal, berada pada ujung ventral lidah, tidak memiliki tangkai, permukaan halus, muncul sekitar \pm 5 hari yang lalu, awalnya sakit namun pada saat pemeriksaan tidak terdapat rasa sakit. Gambaran lesi pasien dapat dilihat pada Gambar 1.

\section{MANAJEMEN KASUS}

Berdasarkan hasil pemeriksaan, diagnosis yang ditegakkan yaitu other and unspecified lesion pada mukosa oral berupa lesi hematoma (Kode ICD 10= K137) dengan diagnosis pembanding yaitu ekimosis dan hemangioma. Tidak perlu dilakukan perawatan untuk kasus ini, pasien di edukasi terkait lesi yang ada dan diintruksikan untuk datang kontrol \pm 1 minggu kemudian.

Setelah 10 hari kemudian, pasien datang untuk melakukan evaluasi lesi pada lidahnya. Pada ventral lidah terlihat bahwa lesi merah sudah menghilang dan tidak terdapat sisa jaringan. Pasien juga tidak merasakan sakit. Selain itu, pada daerah ujung ventral lidah tidak terdapat trauma berulang. Gambaran lesi pada saat kontrol dapat dilihat pada Gambar 2.

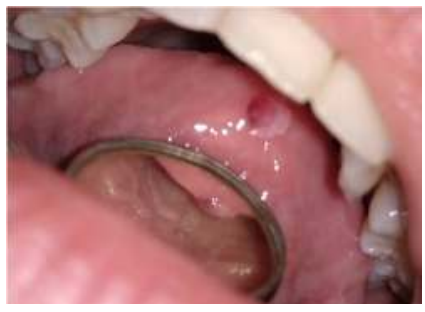

Gambar 1. Lesi Intraoral Hematoma

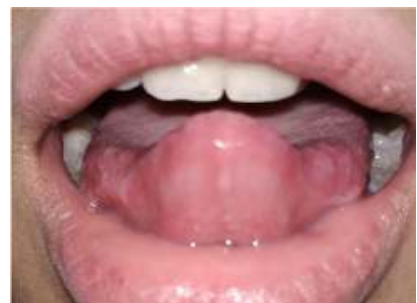

Gambar 2. Lesi pasca 10 hari, lesi merah sudah hilang 


\section{DISKUSI}

Hematoma merupakan kondisi adanya gumpalan darah yang terlokalisir pada mukosa. Etiologi dari lesi ini dapat berupa penurunan jumlah platelet atau faktor penggumpalan darah. Selain itu dapat terjadi perdarahan pada mukosa akibat gangguan vascular maupun dinding pembuluh darah yang sobek akibat trauma.3.6

Secara klinis, hematoma merupakan ekstravasasi darah yang membentuk sebuah massa. ${ }^{4}$ Pada laporan kasus ini muncul lesi merah di ventral ujung lidah dengan ukuran 2 $\mathrm{mm}$. Ukuran massa ini dapat lebih besar atau lebih kecil tergantung pada komponen reaksi inflamasi dan respons penyembuhan yang berlebihan. Gambaran klinis terlihat adanya massa berbentuk dome-shaped dengan permukaan halus dalam berbagai warna mulai dari pucat ke merah muda ke merah terang.

Trauma yang tumpul dapat menyebabkan perdarahan akibat adanya pembuluh darah yang sobek. Pembuluh darah kapiler yang terkena trauma dan sobek akan mengektravasasi darah ke jaringan ikat perivascular. ${ }^{7}$ Hematoma biasanya berada di superfisial yang kemudian dapat menimbulkan massa bengkak kebiruan dari mukosa. Pada lesi ini terdapat peninggian dan konsistensinya cukup kenyal. Awal lesi akan berwarna merah gelap atau biru gelap karena adanya pemecahan hemoglobin menjadi hemosiderin. Umumnya, hematoma tidak menimbulkan rasa sakit atau keluhan dari pasien. Selanjutnya gumpalan darah tersebut akan terdegradasi oleh jaringan di sekitarnya dan akhirnya menghilang.7.9

Perbandingan diagnosis berupa ekimosis dan hemangioma. Ekimosis merupakan perdarahan pada kulit atau membran mukosa akibat ekstravasasi darah ke jaringan subkutan yang berukuran $\pm 1 \mathrm{~cm}$. Ekimosis berbentuk eritema yang berhubungan dengan adanya gangguan perdarahan namun tidak terkait dengan komponen pembuluh darah atau vena. Pada beberapa kasus perdarahan lainnya, ekimosis dapat muncul dalam bentuk lesi berupa bulla berisi darah pada rongga mulut.' Hemangioma merupakan tumor jinak kongenital pada sel endotel pembuluh darah yang mengalami proliferasi. Hemangioma jaringan lunak umumnya muncul pada bagian dorsum lidah, gingiva, dan mukosa bukal.1.8 Hemangioma kapiler berupa lesi benwarna merah, biru, atau ungu, datar atau sedikit menonjol, permukaannya halus dan sedikit keras, sedangkan hemangioma kavernosus dapat berupa makula atau terkadang nodula yang cenderung warnanya sama dengan warna permukaan mukosa bila letaknya berada di jaringan ikat. 8

Penting untuk praktisi atau operator untuk mengetahui penyebab terjadinya perdarahan/ hemoragi dan hubungannya dengan penyakit sistemik yang diderita pasien. Hematoma biasanya tidak membutuhkan perawatan bila tidak berhubungan dengan morbiditas atau penyakit sistemik. Pasien tetap perlu dilakukan edukasi terkait lesi yang ada serta lakukan upaya untuk menghilangkan etiologi yaitu trauma tergigit. Selain itu, dilakukan edukasi kesehatan gigi dan evaluasi lesi selama \pm 1 minggu. Sedangkan hematoma yang besar biasanya membutuhkan beberapa minggu untuk menghilang. Jika hematoma terjadi secara sekunder akibat adanya gangguan sistemik, maka perawatan yang diberikan yaitu kontrol penyakit tersebut terlebih dahulu. ${ }^{4}$

Lesi oral akibat adanya trauma relatif umum ditemukan pada pemeriksaan dental. Hematoma adalah hasil ekstravasasi darah yang besar akibat trauma sehingga menimbulkan massa. Etiologinya berupa trauma pada mukosa atau akibat adanya gangguan perdarahan secara sistemik. Lesi ini berbentuk massa, ukuran $\pm 2 \mathrm{~mm}$, tunggal, berwarna merah gelap, konsistensi kenyal, berada pada ujung ventral lidah, tidak memiliki tangkai, permukaan halus. Umumnya, hematoma tidak menimbulkan rasa sakit atau keluhan dari pasien. Lesi akibat perdarahan ini dapat terdegradai oleh jaringan sekitarnya, sehingga tidak perlu dilakukan perawatan. Pada kasus ini dilakukan edukasi dan evaluasi lesi selama \pm 1 minggu. Hematoma menghilang sendiri tanpa ada perawatan.

\section{UCAPAN TERIMA KASIH}

Penulis mengucapkan terimakasih kepada dosen bagian ilmu penyakit mulut, pendidikan profesi, jurusan kedokteran gigi, Universitas Jenderal Soedirman yang telah membimbing dalam terbitnya jurnal laporan kasus ini.

\section{KONFLIK KEPENTINGAN}

Penulis telah menyatakan bahwa tidak ada konflik kepentingan.

\section{DAFTAR PUSTAKA}

1. Langlais RP, Miller CS, Nield-Gehrig JS, Atlas Berwarna Lesi Mulut yang Sering Ditemukan 4rd ed, EGC, Jakarta. 2013

2. Pillai AK, Kumar JA, Moghe S, Vishnu V, Trauma and Sharp Tooth Induced Labial Vestibule Hematoma in a Patient with Elevated International Normalized Ratio IOSR JDMS, 2014: 13(9):45-8.

3. Ibsen OAC., Phelan JAP, Oral Pathology for the Dental Hygienist With General Pathology Introductions, Seventh Edition, Elsevier, Missouri. 2008

4. Neville BW, Damm DD, Allen CM, Chi AC, Oral Atlas of Oral and Maxillofacial Diseases, Elsevier, Philadelphia. 2019 
5. Reyes MA, Eichenfield LF, Clinical Syndromes and Cardinal Features of Infectious Diseases: Approach to Diagnosis and Initial Management, Elsevier, Philadelpia. 2012

6. Lewis SL, Dirksen SR, Heitkemper MM, Bucher L, Medical-Surgical Nursing : Assessment and Management of Clinical Problems, Ninth Edition, Elsevier, Canada. 2014
7. Anil GG, Savita AG, Textbook of Oral Medicine, Jaypee Brothers, India. 2014

8. Rohan U, Oral hemangioma or vascular malformation: Different entities, IAOMR, 2016; 27(3):497-9.

9. Pinto A, Haberland CM, Pediatric Soft Tissue Oral Lesions, Dent Clin N Am, $2014 ;(58): 17-9$ 